\title{
Pelatihan Press Release Sebagai Media Mengenalkan Bisnis Baru Home Industri Kreasi Limbah Plastik Potensi Unggulaan Desa Wringinputih Kecamatan Bergas Kabupaten Semarang
}

\author{
Dheasey Amboningtyas, Leonardo Budi Hasiholan \\ Fakultas Ekonomi Universitas Pandanaran, Indonesia \\ Email: dheasey@unpand.ac.id/leonardobudihas@yahoo.com
}

\begin{abstract}
ABSTRAK
Desa Wringinputih merupakan salah satu Desa di Kabupaten Semarang yang masih banyak memiliki warga miskin. Potensi yang akan diangkat dari Desa Wringinputih adalah kreasi limbah plastik yang bertujuan selain mengurangi limbah plastik di desa tersebut sehingga bisa menjaga kesehatan dan kelestarian alam juga bermaksud meningkatkan kesejahteraan karena memiliki niai jual. Dimana limbah plastik merupakan salah satu ikon yang ada di desa Wringinputih dalam kurun 3 tahun terakhir. Tujuan utama yang ingin dicapai dalam pelaksanaan program pengabdian di Desa Wringinputih adalah menjadikan limbah plastik sebagai bahan baku andalan untuk wirausaha sehingga bisa dimaksimalkan dalam produksi kreasinya baik yang bisa dimanfaatkan untuk hiasan maupun alat sekolah. Sehingga lebih lanjut mampu meningkatkan taraf hidup masyarakat Wringinputih melalui usaha pembuatan berbagai kerajinan tangan yang terbuat dari bahan baku plastik (limbah). Diharapkan dengan adanya sarana ini akan mampu menjadikan Desa Wringinputih sebagai sentra penghasil kreasi kerajinan tangan berbahan dasar plastik (limbah)yang dikenal seantero provinsi Jawa Tengah khususnya dan Indonesia pada umumnya.Tujuan lain yang ingin dicapai adalah adanya keahlian yang dimiliki para entrepreneur pengrajin tersebut dalam membuat kreasi dari limbah plastik, sehingga sewaktuwaktu bisa dimanfaatkan untuk dipublikasikan di media massa dan pada akhirnya bisa menginspirasi banyak daerah untuk bisa melakukan hal yang sama. Terkait dengan kegiatan yang dilakukan oleh para entrepenur ketika memproduksi kerajinan aksesories, perlengkapan sekolah dan hiasan furniture rumah tangga dan perkantoran tentunya. Dari program pengabdian di Desa Wringinputih Kecamatan Bergas Kabupaten Semarang indikator capaian yang akan dituju yaitu : meningkatnya partisipasi masyarakat dalam mengolah dan mengkreasikan limbah plastik (bekas bungkus kopi, snack, mie instan, tas plastik, dan lain sebagainya, terjalinnya kerjasama antara masyarakat Desa Wringinputih dengan instansi terkait dalam pengembangan kreasi limbah plastik, bertambahnya produsen pengrajin berbahan dasar limbah plastik, meningkatnya ketrampilan masyarakat dalam membuat pemeran untuk memasarkan hasil kreasinya sehingga aneka jenis kerajinan limbah plastik lebih dikenal melalui publikasi baik di media cetak, on line dan media sosial yang meliput sewaktu pameran tiba, sehingga dapat menciptakan lapangan pekerjaan bagi masyarakat Desa Wringinputih khususnya ibu-ibu anggota PKK atau Tim Pemberdayaan Perempuan, yang pada akhirnya dapat meningkatkan taraf perekonomian, tumbuhnya industri rumah tangga yang mengolah limbah plastik menjadi berbagai jenis kerajinan hiasan rumah dan perkantoran, terbentuknya suatu sentra produksi khusus untuk pengolahan hingga penjualan hasil kreasi limbah plastik.
\end{abstract}

Kata Kunci: Kreasi, Limbah Plastik, Hiasan Rumah Tangga

\section{PENDAHULUAN}

Wringin Putih adalah sebuah desa di kecamatan Bergas, Semarang, Jawa Tengah Indonesia. Sebagaian besar wilayah desa ini merupakan wilayah perkebunan karet PTP XVIII Ngobo. Desa ini terdiri atas 5 dusun, yakni: Wringinputih, Dendeng, Ngobo, Pluwang dan Watugajah. Kondisi perekonomian di Desa Wringinputih digolongkan masih dalam taraf rendah, karena banyaknya penduduk usia produktif yang didominasi memiliki pekerjaan sebagai buruh dan karyawan swasta. Warga Desa Wringin putih belum mampu meratakan tingkat ekonomi desanya, serta banyak dari warga ini yang masih menganggur, sehingga belum mampu meningkatkan ekonomi keluarga. Desa Wringinputih merupakan salah satu 
di wilayah Kecamatan Bergas Kabupaten Semarang yang masih banyak memiliki warga miskin.

Berdasarkan dari hasil pendataan monografi Desa Wringin putih bulan JuniDesember 2019, lebih dari 50\% penduduknya bermata pencaharian sebagai buruh, hal ini disebabkan oleh kondisi geografis yang kurang strategis serta sumber daya manusia yang sangat terbatas terutama dari tingkat pendidikan. Banyak dari warga Desa Wringinputih memiliki usaha individu seperti kerajinan membuat sapi ijuk, lidi dan pengolahan limbah plastik. Namun masih belum bisa mengembangkan usaha tersebut. Sehingga berdasarkan kondisi masyarakat Desa Karangsari di atas program pengabdian melalui "Pelatihan Press Realease Sebagai Media Mengenalkan Bisnis Baru Home Industri Kreasi Limbah Plastik Potensi Unggulan Desa Wringinputih Kecamatan Bergas Kabupaten Semarang”. Diharapkan dengan adanya pelatihan tersebut mampu membantu meningkatkan taraf ekonomi warga Desa Wringinputihdan mampu meningkatkan taraf ekonomi desa. Kewirausahaan dengan memaksimalkan Pemberdayaan Masyarakat dengan memanfaatkan potensi lokal yang ada adalah kata kunci untuk membangun desa. Desa yang berdaya adalah desa yang dengan mandiri merumuskan program pembangunannya seiring sejalan dengan memanfaatkan potensi dan latar belakang serta hirarki desa tersebut. Kewirausahaan merupakan persoalan penting di dalam perekonomian suatu bangsa yang sedang sedang gencar-gencarnya membangun. Kemajuan atau kemunduran ekonomi suatu bangsa ditentukan oleh keberadaan dan peranan dari kelompok entrepreneur ini (Sulandjari, 2017:17).

\section{METODE PELAKSANAAN}

\section{Waktu dan Tempat}

Tempat pelaksanaan kegiatan Pengabdian Kepada Masyarakat tahun 2019 Universitas Pandanaran Semarang ditetapkan di Desa Wringinputih Kecamatan Bergas Kabupaten Semarang.

\section{Metode}

1. Penyuluhan memberdayakan masyarakat dalam pengolahan sampah/limbah plastik yang ada dalam rumah tangga masing-masing sudah terlaksana dengan maksimal

2. Memberikan pelatihan pembuatan press release sebagai bentuk publikasi olahan dari limbah plastik menjadi produk-produk yang memiliki nilai jual tinggi (value) sudah dilakukan dengan optimal pula.

3. Memberikan sosialisasi tentang manfaat literasi media bagi pertumbuhan dan perkembangan IQ, EQ, SQ dalam keluarga sangat besar

4. Memberikan sosialisasi kepada masayarakat Desa Wringinputih Kecamatan Bergas Kabupaten Semarang melalui pihak Kepala Desa dan aparat Desa, Ketua RW dan RT tentang program-program yang akan dilaksanakan dalam kegiatan Pengabdian Kepada Masyarakat.

5. Melaksanakan monitoring secara berkala untuk mengetahui dampak capaian dari program-program Pengabdian Kepada Masyarakat yang dilaksanakan.

\section{Kontribusi Partisipasi Mitra}

Partisipasi mitra dalam pelaksanaan pelatihan Press Realease adalah:

1. Mengumpulkan seluruh Kelompok Warga Wringin Putih, maka diikutsertakan pula Kelompok diperlukan kerjasama yang baik antara pihak akademisi (universitas), 
masyarakat setempat, petani belimbing, TIM Pemberdaya Perempuan, Pemerintah Kota maupun swasta.

2. Menyediakan tempat pelaksanaan penyuluhan dan pelatihan.

3. Menyediakan bahan dan alat pendukung.

\section{HASIL KEGIATAN}

Kegiatan pelatihan Press Release yang dititikberatkan pada program Pengabdian Kepada Masyarakat Universitas Pandanaran di Desa Wringinputih adalah peningkatan taraf hidup masyarakat di wilayah Desa Wringinputih melalui pemberdayaan masyarakat di sektor usaha kecil pembuatan kerajinan tangan olahan berbahan dasar limbah plastik. Programprogram yang telah dilaksanakan di Desa Wringinputih diharapkan mendapat respon yang baik dari masyarakat dan ditindaklanjuti masyarakat setempat sehingga dapat meningkatkan taraf hidup dan kesejahteraan masyarakat Desa Wringinputih dengan mengadakan monitoring yang berkelanjutan untuk mengetahui perkembangan kerajinan yang dibuat dari bahan baku limbah plastik..

\section{KESIMPULAN}

Kegiatan Program Pengabdian Kepada Masyarakat yang dilaksanakan oleh Universitas Pandanaran dengan Kegiatan Pelatihan Administrasi PKK berjalan dengan baik dan lancar. Upaya peningkatan motivasi dan pemahaman press release warga wringin putih di Kecamatan Bergas Kota Semarang membuahkan hasil meskipun tidak dapat dipastikan seberapa tinggi hasil yang diperoleh. Para peserta yang hadir mengikuti pelatihan termotivasi untuk bersemangat aktif dalam segala bentuk kegiatan press release. Dengan semangat yang dimiliki selama kegiatan, peserta pada akhirnya mampu mengimbangi dan menyerap informasi panduan pengisian rekapitulasi data admistrasi. Namun kegiatan ini juga memiliki keterbatasan. Keterbatasan yang pertama yaitu waktu pelatihan dan fasilitas peralatan yang minim. Permasalahan pemenuhan kekurangan buku administrasi terselesaikan meskipun harus menggunakan uang yang dihimpun dari iuran para anggota. Keterbatasan yang lain yaitu kurangnya antusias para peserta undangan sehingga jumlah yang hadir kurang dari yang diharapkan.

\section{UCAPAN TERIMAKASIH}

Penulis mengucapkan terima kasih kepada Lembaga Penelitian dan Pengabdian Kepada Masyarakat Universitas Pandanaran dan Fakultas Ekonomi yang telah membiayai pengabdian ini pada Tahun Anggaran 2020. Penulis juga mengucapkan terimakasih kepada Warga Wringin Putih Kecamatan Bergas atas partisipasinya dalam kegiatan pengabdian ini

\section{DAFTAR PUSTAKA}

Sulandjari, Rekno. 2017. Kewirausahaan Pada Keunggulan Lokal. Jakarta:Pustaka Tunggal

I Dewa, Nyoman Supariasa. 2001. Penilaian Status Gizi. Jakarta: EGC

Hariyani Sulistyoningsih. 2011. Gizi untuk Kesehatan Ibu dan Anak. Yogyakarta: Graha Ilmu.

Sunita Almatsier. 2002. Prinsip Dasar Ilmu Gizi. Jakarta: PT. Gramedia PustakaUtama.

Judhita, Christiany. 2013. Literasi Media Pada Anak Di Daerah Perbatasan Indonesia Dan Timor Leste.JurnalIPTEKKomunikasi.15(1).47-62. 
Tamburaka, Apriadi. 2013. Lierasi Media: Cerdas Bermedia Khalayak Media Massa. Jakarta: Rajawali Pers.

Soemirat, Soleh dan Ardianto, Elvinaro. 2004. Dasar-dasar Public Relations. Cetakan Ketiga. Bandung :Remaja Rosdakarya 